\title{
Droga berriak merkatu berritzailean
}

\author{
New drugs in an innovative market \\ Igor Horrillo ${ }^{1,2,3}$ eta Luis F. Callado ${ }^{1,2,3}$ \\ ${ }^{1}$ Farmakologia Saila, Euskal Herriko Unibertsitatea, UPV/EHU \\ ${ }^{2}$ Centro de Investigaciones Biomédicas en Red de Salud Mental (CIBERSAM) \\ ${ }^{3}$ Biocruces Osasun Ikerketa Institutua \\ igor.horrillo@ehu.eus
}

\section{Laburpena}

Egundaino ezagunak diren drogak, heroina kasu, legez kanpo daude eta haien eraginak ezagunak dira. 2005. urtetik hona, ehunka droga berri jarri dira merkatuan eta gehienen egitura kimikoa ezaguna bada ere, kasu askotan hori da haiei buruz dugun informazio guztia. Droga horiek sintetizatzen dituzten laborategi klandestinoen helburua ohiko drogen eragina imitatzea da, baina eragin ezezaguneko substantziak ekoizten dituzte. Eraginak ez ezik profil toxikologikoa edo dosi hilgarria ere ezezagunak izaten dira, saldu aurretik ikertu gabeko substantziak izaten baitira. Hala ere, eragin eta toxikologia ezezaguneko substantziak izanik, substantzia horietariko gehienen salmenta ez dago legez kanpo, ezta kontrolpean ere. Egun bizi dugun iraultza teknologikoak, Internet dela medio, substantzia berri horien merkaturatzea errazten du gainera.

Gako-hitzak: droga berriak, psikoaktiboa, diseinu-droga, haluzinatzaileak

\section{Abstract}

Nowadays there are well-known drugs, such as heroin, which are illegal and their effects are well known. Since 2005, many new drugs have been put on the market and although we know their chemical structure, in many cases this is all the information we have about them. These drugs are synthesized in clandestine laboratories and try to mimic the effect of conventional drugs, but they produce substances whose effects are currently unknown. Moreover, their toxicological profiles and lethal doses are also unknown. In spite of these issues, the sale of the majority of them is not illegal and is unregulated legally. The current technological revolution, associated to a large extent with the Internet, also facilitates the efficient marketing of these new substances.

Keywords: New drugs, psychoactive, design drugs, hallucinogen 


\section{Sarrera}

Azken urte hauetan, uda heltzean, komunikabideek droga berrien berri ematen digute eta horien eragin arriskutsuak azpimarratu: duela hiru urte "droga kanibala» izan zen eta duela bi "flakka» deritzona. Baina, zein da egun droga berriek gizartearentzat ekartzen duten arriskua? Izan ere, gure inguruan duten agerpen eskasa dela-eta, arriskua ez da handia, baina gerora begira, arriskua lazgarri bilaka daiteke. Arazo horri irtenbidea aurkitu nahian, hainbat elkarte sortu dira kaleko drogak aztertzeko. Gainera, Europar Batasunak hainbat saiakera egin ditu arazoari konponbidea bilatu nahian: zenbait erakunde sortu ditu droga horien detekzio goiztiarra egiteko eta Internet bidez substantzia psikoaktiboak saltzen dituzten denda birtualak kontrolatzeko.

\section{Kontsumoaren inguruko datuak}

2015ean argitaratu zen Munduko Nazioen Elkarteko txostenaren arabera, 541 substantzia psikoaktibo berri daude salgai 95 lurraldetan banaturik 2009. urtetik (1). Substantzia berrien zenbatekoaren hazkuntza handituz doa abiadura bizian (1. irudia). 2015. urtean zehar 98 substantzia berri jarri ziren merkatuan Europar Batasuneko droga-menpekotasunen behatokiren (EMCCDA) arabera (2).

1. irudia: 2009 eta 2014 bitartean merkaturatu diren substantzia psikoaktibo berrien kopurua (UNODC, substantzia psikoaktibo berrien detekzio goiztiarra, 2009-2014).

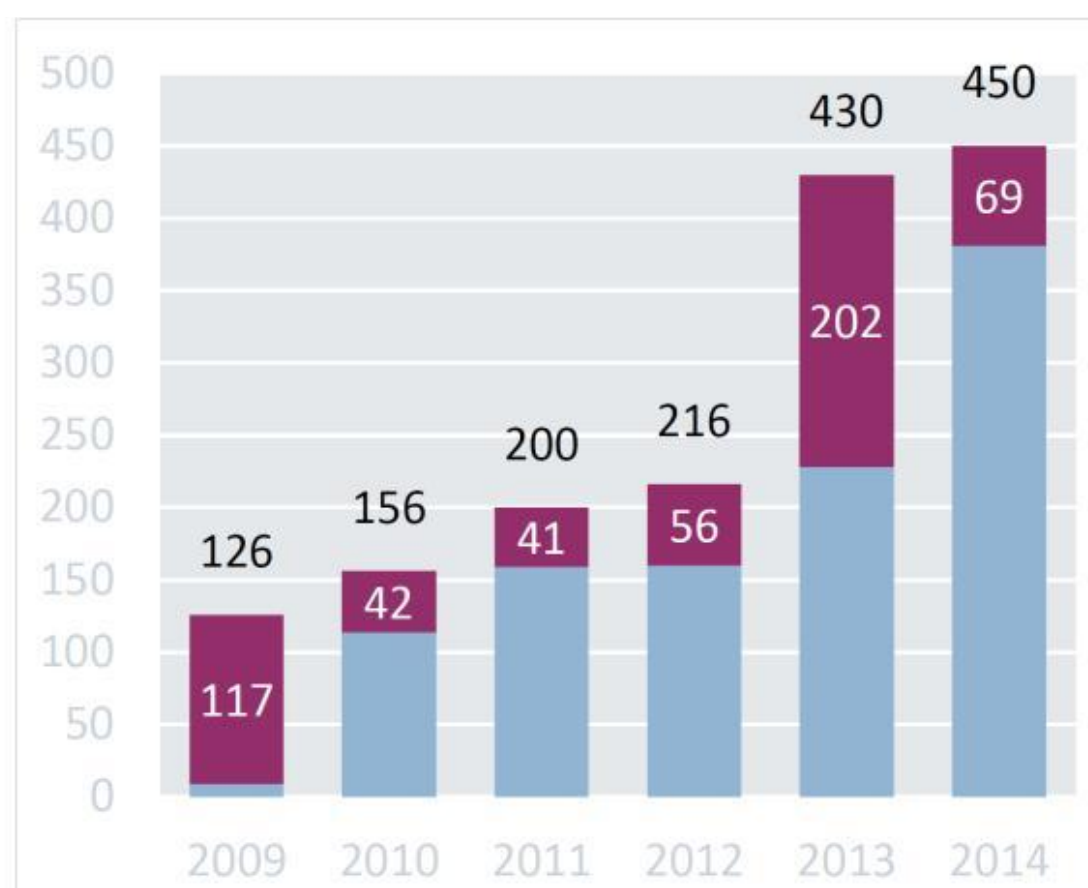

Lehenengo aldiz urte horretan detektatu diren substantzia psikoaktibo berrien zenbatekoa.

Urte horretan ezagunak ziren substantzia psikoaktibo berrien zenbatekoa.

Erabileraren prebalentziari buruz, aldiz, oso informazio gutxi argitaratu da. Herrialde gutxi dira substantzia psikoaktibo berrien kontsumoaren inguruan kontrola egiten dutenak: Estatu Batuak eta Europar Batasuneko hainbat estatu, behinik behin. Espainia, 2012. urtean hasi zen substantzia berri hauen jarraipena egiten. Kontsumoaren prebalentziari dagokionez, Droga eta Toxikomanien Jarraipenerako Espainiako Behatokiak (OEDT) 2015ean argitaratu zuen EDADES 2013 estatistiken txostenean kontuan hartuak izan ziren substantzia psikoaktibo berriak (3). Horren arabera, 15 eta 65 urte bitarteko biztanleen artean substantzia psikoaktibo berrien kontsumoaren prebalentzia \% $3 \mathrm{koa}$ da, 15 eta 34 urte bitarteko biztanleria izanik prebalentzia handiena agertzen duena $(\% 4,9)$ da. Hala 
ere, biztanleen \% 74,1ek dio ez duela izan substantzia psikoaktibo horien berri. Azterlan honen arabera, espainiarren artean substantzia horien kontsumoa esperimentala da eta gizonezkoen artean erabiliagoak izaten dira. Bestalde, Energy Control erakundeak egindako kaleko detekzio-lanetan 290 lagin aztertu zituzten Espainiako Estatuan zehar 2015. urtean eta horien artean 81 substantzia psikoaktibo berri ezberdin detektatu zituzten. 2014. urtean, berriz, 240 laginetan 55 substantzia ezberdin detektatu zituzten (4).

2016. urtean, berriz, ESTUDES 2012 galdeketaren txostena argitaratu zen. Txosten horren arabera 14 eta 18 urte bitarteko ikasleen artean "substantzia berrien» kontsumoaren prebalentzia \% 4koa da (\% 4,8 mutilen artean eta \% 3,3 nesken artean). Droga berrien artean perretxiko haluzinatzaileak izango lirateke gazteen artean gehien kontsumitzen direnak.

2. irudia: 2014. urtean merkaturatu ziren substantzia psikoaktiboen taldeak (UNODC, substantzia psikoaktibo berrien detekzio goiztiarra, 2009-2014).

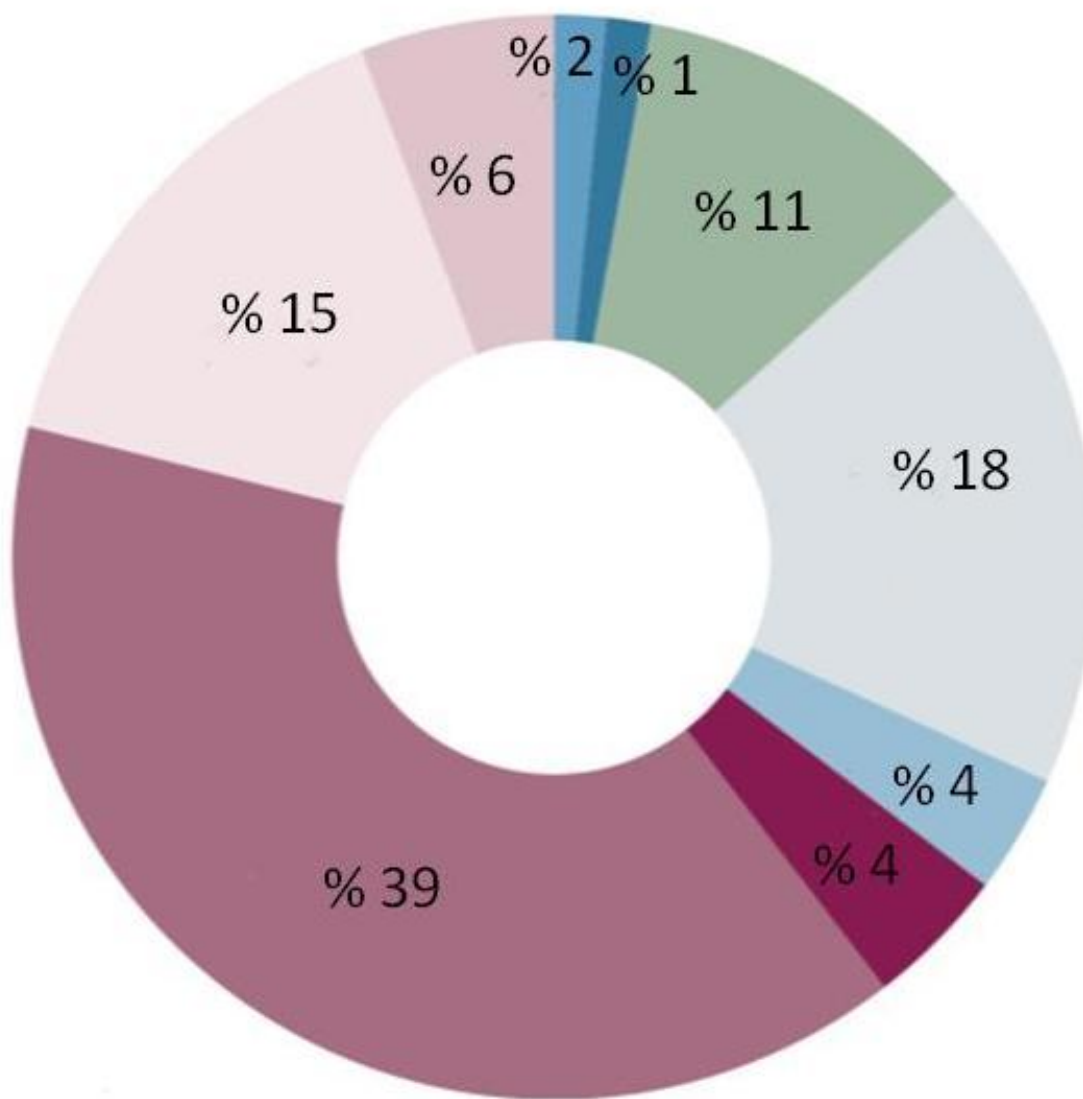

Aminoindanoak

Ketaminaren antzeko substantziak

Beste substantzia batzuk

Feniletilaminak
Piperazinak

Landare-jatorria duten substantziak

Kannabinoide sintetikoak

Katinona sintetikoak

Triptaminak

Euskal Autonomia Erkidegoan kalamuak, kokainak eta anfetaminek jarraitzen dute izaten droga ilegal kontsumituenak. Hala ere, ez ditugu ezagutzen azken urteetako kontsumo-tasak ez substantzia berriek izan duten agerpena, ez baita txosten berririk argitaratu 2012tik hona. Daukagun informazioa poliziak harrapatutako substantzien ingurukoa da. Horien arabera, Gobernuaren Osasun Saileko Euskadiko laborategietan 34 substantzia psikoaktibo berri aztertu ziren 2016. urtean, eta horietariko 6 lehenengo aldiz deskribatu ziren Espainiako Estatuan: 2CB-fly, 3,4 CTMP, BB-22, BK-2CB, MDAI eta NM-2Al. Detektatutako substantzia berrien zenbatekoa nabarmen igo da 2015 . urtetik, non 3 
substantzia berri besterik ez ziren detektatu. Arrisku-murrizketen aldeko Ai Laket erakundeak, berriz, 5 substantzia psikoaktibo berri detektatu zituen 2014. urtean, kaleetan egiten dituzten azterketetan (5).

Espainiako Estatuan bada Droga Berrien Detekzio Goiztiarrerako programa (SEAT) daraman erakundea, zeina 2013. urtean eratu zen Europar Batasunaren agindupean. Erakunde horren funtzioa substantzia psikoaktibo berriak detektatu eta haien inguruko informazio fidagarria banatzea litzake. Haren arabera, 2013. urtean 18 substantzia berri detektatu ziren, 2014an 17 eta 2015. urtean 35.

\section{Internet eta egungo legedia}

Egun gure inguruan substantzia psikoaktibo berrien agerpena oso garrantzitsua ez bada ere, balizko arriskua oso handia da. Izan ere, substantzia berri gehienak ez daude legez kanpo. Ezezagunak diren heinean, legeak ezin ditu kanpoan utzi. Horretaz gain, legegintzaren abiadura droga horien sintesiabiadura baino motelago doa beti. Legez kanpo ez egote horrek merkatuan libreki mugitzea dakar, eta, Internet sareak gizartean duen eragina kontuan izanda, agerian dago substantzia berriek aurkez dezaketen arriskua handia dela.

Balizko arrisku horren jarraipena egiteko, 2006. urtean substantzia psikoaktibo berriak sarean saltzen zituzten denda birtualei jarraitzeko erakunde bat sortu zen Europar Batasunean. 2010. urtean 109 denda detektatu ziren 15 lurraldetan banaturik eta 2012. urtean 693 detektatu ziren 20 lurraldetan. Espainiako Estatuan ere 2013. urtean 11 denda aurkitu zituzten eta gehienak jatorri naturaleko substantzien saltzaileak ziren. Denda birtual horiek modu irekian saltzen dituzte substantzia psikoaktiboak eta posta arruntez baliatuz banatzen dituzte inongo trabarik topatu gabe erosleak jaso artean (6).

Egoera horri aurre egiteko, azken urteotan ahalegin handia egin da Europar Batasuna osatzen duten lurraldeek legediak alda ditzaten, substantzia horien salmenta mugatzeko asmoz. Horren ondorioz, Espainiako Estatuan 11 substantzia legez kanpo utzi dira azken hamar urteetan. Gainera, 2017. urtean kontrolpean jarri dira drogen sintesirako erabiltzen diren hainbat lehengai, 2009. urtean Europar Batasunak adostutako legeari jarraituz (7).

\section{Droga talde ezberdinak}

Aurretik aipatu bezala, egun merkatuan dauden substantzia psikoaktibo berriak ohiko drogen eraginak imitatzeko asmoz sortu ziren. Substantzia berri hauek sortzeko, jatorrizko substantziaren egitura kimikoan aldaketa txikiak eragiten zituzten, anfetamina berriekin adibidez. Horrela, legez kanpo ez dauden substantzia berriak sortu ziren. Gainera, substantzia berri hauek eragin ezberdinak ere izan ditzakete; izan ere, kasu batzuetan potentzia handiagoa duten substantzia berriak lortu dira eta beste batzuetan eragin gehigarriak dauzkaten substantziak, anfetamina haluzinatzaileak adibidez. Izan ere, egitura kimikoan egindako aldaketak txikiak izan daitezkeen arren, eragin farmakologikoan aldaketa handia eragin dezakete.. Beste kasu batzuetan, kannabinoide sintetikoak kasu, egitura kimiko guztiz ezberdinak lortu dira antzeko eragin farmakologikoak lortzeko. Izaera kimiko ezberdina izate horrek asko zaildu ditu substantzia berrien detekziorako lanak laborategietan. Urteak aurrera egin ahala, gero eta talde kimiko gehiago sartu dira substantzia psikoaktibo berrien artean: anfetaminaren analogoak, kannabinoide sintetikoak, katinona sintetikoak, piperazinak, landarejatorriko substantziak, ketaminaren antzeko substantziak, etab.

\subsection{Anfetaminaren analogoak edo feniletilaminak}

Feniletilaminen taldea substantzia ezberdin ugariz osatutako talde zabala dugu. Talde honen barruan eragin pizgarria (anfetamina klasikoak), entaktogenoa (3,4-metilendioximetanfetamina edo MDMA, eta haren eratorriak) edo haluzinatzailea (metoxianfetaminak) izan dezaketen substantziak daude (8). Efektu bat edo bestea sortzeko ahalmena neurotransmisore ezberdinekiko duten eraginaren, emandako dosiaren eta kontsumitzaile bakoitzaren ezaugarrien araberakoa izango da. 


\section{Errebisio-artikulua}

Era berean, talde honen barruan azpitalde batzuk ditugu, egitura kimikoaren arabera sailkatuak. Guztiek dute, hala ere, eragin farmakologikoaren erantzule den antzekotasun amankomun bat: feniletilamina egitura kimikoa, monoamina neurotransmisoreen antzekoa delako (3. irudia).

3. irudia: Feniletilamina egitura duten substantzia psikoaktibo berrien eta monoamina neurotransmisoreen egitura kimikoak.<smiles>NCCc1ccccc1</smiles><smiles>NCCc1c[nH]c2ccc(O)cc12</smiles><smiles>CC(N)Cc1ccccc1</smiles>

Anfetamina<smiles>NCC(O)c1ccc(O)c(O)c1</smiles><smiles>CNC(C)Cc1ccc2c(c1)OCO2</smiles>
3,4-metilendioximetanfetamina (MDMA)<smiles>NCCc1ccc(O)c(O)c1</smiles>

Dopamina<smiles>CNC(C)Cc1ccc(OC)cc1</smiles>

p-metoximetanfetamina (PMMA)

Oro har, feniletilaminek neuronen neurotransmisoreen askapena bultzatzen dute haien lekua ordezkatuz (9). Substantzia hauek kontsumitu ondoren, gehiegizko askapenaren ondorio gisa serotoninaren eta dopaminaren gabezia gertatzen da. Gabezia horrek 24 ordu inguru iraungo du eta kontsumitzaileak 2-3 egun beharko ditu aurreko egoera normalera bueltatu arte. Fenomeno hori dela-eta, kontsumitzaile askok energia falta, geldotasuna eta depresioa pairatuko dituzte substantziaren kontsumoa eten ondoren. Gainera, kontsumo kronikoak neurotoxikotasuna sortuko du eta neuronen galera eragingo.

Azken urteotan, talde honen barruan garrantzi gehien hartu duen substantzia PMMA dugu. PMMA parametoxianfetamina da eta "superman» ezizenez ezagutu da, zeren substantzia arriskutsu hau daukaten pilulek supermanen ikurra baitute azalean. PMMAk serotoninaren mailak igo eta eragin pizgarria eta entaktogeno indartsuak eragiten ditu. Baina haren arazo nagusia hauxe da: substantzia oso toxikoa dela, gutxieneko dosi eraginkorraren eta dosi toxikoaren arteko tartea oso estua delako. Hori dela-eta, Europan eta Euskal Herrian izandako heriotza batzuk substantzia horren kontsumoarekin lotu dira.

\subsection{Kannabinoide sintetikoak}

Droga sintetiko hauek kalamuaren eragina imitatzea dute helburu (10). Oro har, barne-sistema kannabinoidean dute eragina eta neurotransmisio-sistema horren hartzaileak aktibatzen dituzte. Hala ere, haien afinitatea $\mathrm{CB}_{1}$ hartzaile kannabinoidearekiko $\Delta^{9}-\mathrm{THC}$-ak duena baino 20 aldiz altuagoa izatera hel daiteke. Beraz, kalamuaren antzeko eraginak izango dituzte (euforia, kitzikapena, barrea, gose-eza...), baina efektua askoz indartsuagoa izango da. Horregatik, intoxikazioa eta eragin kaltegarriak (takikardia, aho lehorra, begien gorritasuna, ataxia, ikara-atakeak...) agertzeko arriskua ere handiagoa izango da.

Kannabinoide sintetiko hauek Interneten bidez saltzen dira, legalak diren eta eragin psikoaktiboa izan dezaketen beste landare exotiko edo aromatiko batzuekin (Pidecularis densiflora, Leonitis leonurus...) batera nahastuta. Baina kasu gehienetan, eskainitako landarea ez da izaten benetan droga osatzen 
duena. Aztertutako produktu asko ohiko landare aromatikoak izaten dira, eta horiei kannabinoide sintetikoak gehitzen zaizkie eragin psikoaktiboak izan ditzaten.

Produktu hauek «spice» edo "K2» ezizenez saltzen dira. Research Chemical gisa ere saltzen dira, hau da, ikerkuntzarako produktu kimikoak izango balira moduan. Gainera, produktu kimiko gisa saltzen direnean, "produktu hau ez da giza kontsumorako erabilgarria» oharra eramaten dute. Produktu kimiko hauek substantziaren benetako izen generikoa erabiltzen dute (JWH-018, HU-210, CP47.497...) eta hauts zuri forman eskaintzen dira.

\subsection{Katinona sintetikoak}

Katinona, Catha edulis (Khat) landarearen osagai aktiboa da. Landare hau psikoestimulatzaile moduan erabili da betidanik Afrikako lurralde askotan. Gehiegizko kontsumoak psikosia edo bihotzekoa pairatzeko arriskua areagotzen du. Azken urteotan katinonaren analogo sintetiko asko agertu dira merkatuan. Merkaturatutako substantzia psikoaktibo berrien artean hirugarren lekua hartu dute, kannabinoide sintetiko eta feniletilaminen atzetik. Katinonaren analogo hauen artean ezagunena mefedrona da (11). Mefedronak eragin pizgarriak eta entaktogenoak ditu, eta kokaina zein estasiaren alternatiba ohikoena bihurtu da zenbait herrialdetan. Hala ere, mefedronaren kontsumoarekin lotutako intoxikazio eta heriotza batzuk agertu dira zenbait herrialdetan. Gehiegizko kontsumoak takikardia, hipertentsioa, hiperaktibitate motorra, izerdia, hipertermia, antsietatea eta gorakoak eragin ditzake. Mefedrona talde honen ordezkari ezagunena eta zaharrena izanik, Espainiako Estatuan legez kanpo dago 2011. urtetik.

Hartzen diren beste katinonaren analogo sintetikoak hauek dira: etkatinona, 3-flurometilkatinona, metkatinona eta 3,4-metilendioxipirovalerona (MDPV). Azken hori, MDPV, droga kanibal edo zonbi ezizenez ere ezagutu da. Sudur-bidetik hartzen da eta toxikotasun akutuak eragin neurologikoak, kardiobaskularrak eta psikopatologikoak eragiten ditu. Hala nola parkinsona, diskinesiak, takikardia, hipertentsioa, hipertermia, psikosia, ikara-atakeak eta haluzinazioak. Droga honek zuzenean eragindako zenbait heriotza ere agertu dira. Talde berekoa den eta gure artean aurkitu den azken katinona flakka delakoa litzateke. Kimikoki $\alpha$-pirrolidinobalerofenona (alfa-PVP) litzateke eta profil farmakologikoa MDPVrenaren oso antzekoa du. Gure inguruan ospe handirik ez duen arren, Estatu Batuetako ekialdean eragin lazgarriak pairatzen ari dira, eta 2015. urtean 63 heriotza esleitu zitzaizkion (12).

\subsection{Piperazinak}

Piperazinak Estatu Batuetako merkatuan agertu ziren pasa den mendeko 1990eko hamarkadan. Hamar urte beranduago Europan sartu ziren eta haien kontsumoa izugarri hazi da azken urteotan. Party pills, A2, Nemesis, Legal $X$ edo herbal pills ezizenez merkaturatu dira. Pilula hauen osagai nagusia 1-benzilpiperazina (BZP) da, nahiz eta trifluorometilfenilpiperazina (TFMPP) edo 1-3klorofenilpiperazina ere (mCPP) topa daitezkeen. Horietariko asko sendagai berrien ikerkuntzan albo batera utzitako farmakoak dira, espero zen eraginik ez zutelako edo profil toxikologiko onartezina zutelako.

Substantzia hauen ekintza-mekanismoa konplexua da, baina guztiek dute eragin estimulatzaile edo pizgarria. Oro har, serotonina eta dopaminaren askapena bultzatzen dute, haren birxurgapena ere inhibitzen dute, eta haien kontzentrazioa handitzen dute tarte sinaptikoan. Ahoaren bidez hartzen dira pilula moduan. Hartu ondoren, eragin pizgarriak eragingo dituzte. Haien artean, euforia, kitzikapena, urduritasuna, hipertentsioa, takikardia eta dardarak agertuko dira. Intoxikazioa anfetaminek eragindakoaren antzekoa da (13).

Antsietatea, urduritasuna, dardarak, gorakoak eta nahastea paira daitezke. Erresuma Batuan droga hauek eragindako 19 heriotza detektatu ziren 2007 eta 2010 urteen artean. Eragin lazgarri horiek zirela medio, debekatuak izan ziren Europar Batasunean 2008an (8). 


\subsection{Landare-jatorriko substantziak}

Helburu erlijioso edo ohitura zaharrei jarraituz, landare eta onddo batzuk aspaldidanik hartu izan dira kultura ezberdinetan haien eragin psikoaktiboaz gozatzeko. XXI. mendeko mundu globalizatuan substantzia horien kontsumoa hedatu egin da eta gizarte garaikideetara heldu da. Talde honen barruan egitura kimiko, ekintza-mekanismo eta eragin farmakologiko ezberdina duten substantziak aurki ditzakegu landare hauen osagaien artean. Aurreko substantziek ez bezala, talde hau osatzen duten landareak ezagunak dira beren jatorrizko lurraldeetan. Ezagupen horiei esker, talde honetako drogen profil toxikologikoa ezaguna izaten da kasu batzuetan, profil farmakologikoa guztiz ezagutzen ez dugun arren.

\section{Ayahuasca}

Antzinatik Amazonas ibaiaren inguruko tribuek erlijio-erritoetarako erabili izan duten landarenahastez osaturiko edabea da. Kontsumitzaileak zenbait landareren nahasketa bat egosi ondoren, bertatik ateratako erauzkina hartzen du. Nahasketa horretan Banisteriopsis caapi liana eta Psychotria viridis landarearen hostoak aurkitzen dira gehienbat. Lehenengoaren osagai aktiboak monoaminooxidasa entzimaren inhibitzaileak dira (IMAO), harmina eta harmalina hain zuzen. Bigarren landarearen osagaien artean dimetiltriptamina (DMT) haluzinatzailea aurkitzen da. Dimetiltriptamina heste-hodian degradatua izango litzateke, IMAOekin batera hartuko ez balitz. Hori dela-eta, ezinbestekoa da bi landareak batera hartzea DMTak bere eragin haluzinatzailea mantendu ahal izateko. Ayahuascak, eragin lasaigarriak izateaz gain, entzumen- eta ikusmen-haluzinazioak sor ditzake. Euskal Herrian gero eta erabiliagoa den landare-nahastea dugu. Izan ere, azken urteetan, edabe hau hartzeko taldeak ere sortu dira, legez kanpo ez dauden landareak izanik.

\section{Iboga}

Ibogaina da Tabernanthe iboga landarearen sustraietan dagoen osagai psikoaktiboa. Landare hau zuhaitz forman hasten da Hego Afrikan, batez ere Congo herrialdean. Bertan, altxor nazionala da eta tribu askok erabiltzen dute bai ehizan ateratzeko bai eta erlijio-erritoetan ere. Izan ere, dosi txikietan ibogainak eragin estimulatzailea izango luke eta dosi handiagoetan eragin haluzinatzaileak agertuko lirateke. Ibogainaren eragina, gainera, oso luzea da eta 48 ordu baino gehiago iraun dezake. Hasieran nahasmena, agitazioa eta ikara eragiten ditu, baina gorputza ohitzen denean, ikusmen-haluzinazioak agertzen dira.

\section{Salvia}

Salvia divinorum landarea aspaldidanik erabili da Mexikon beherakoak, buruko mina edo erreumatismoa sendatzeko. Baina landare honen eragin psikoaktiboak eragiten dituen osagai aktiboa hostoetan dago eta Salvinorina A du izena. Substantzia hori lehenengo haluzinatzaile ez-alkaloidea dugu. Salvinorina A-k kappa motako hartzaile opioideen agonista indartsua da. Normalean hostoak erreta hartzen da. Eraginaren hasiera 2 minutura nabari da eta 15-20 minutu iraungo du. Oro har, entzumen- eta ikusmen-haluzinazioak deskribatu izan dira. Kontsumitzailearen sentikortasuna, argiarekiko zein inguruko soinuekiko, handiagoa izango da. Batzuetan eragin haluzinogenoak desagertu ondoren, zorabioa, buruko mina eta amnesia ere ager daitezke.

\section{Burundanga}

Burundanga Afrikako yoruba hizkuntzan Hyoscyamus albus landarearen izena da. Landare hau Europan aski ezaguna da eta eragin antikolinergikoa duen alkaloide bat dauka, eskopolamina. Hori antzinatik sorginkerian erabili diren Mandragora autumnale edo Atropa belladona landareetan ere agertzen den osagai aktiboa da. Egun droga gisa erabiltzen dena, eskopolamina bera izango litzateke, burundaga ezizenarekin ezagutzen dena. Burundanga azkenaldi honetan ezagun egin da toxiko moduan erabiltzen delako edari alkoholikoetan nahastuta. Horrela, kontsumitzailearen sedazioa lortuko da, gero lapurtu edo bortxatzeko asmoz. Gainera oroimenean ere eragiten du, gertuko oroitzapenak ahantzarazten dituen amnesia eraginez. Intoxikazio akutuaren ondorioz, aho lehorra, hipertermia, midriasia, ikusmen lausotua edo takikardia ager daitezke. Dosi altuetan ataxia, 
haluzinazioak, delirium edo desorientazioa eragin ditzake, kasu larrienetan koma eta heriotza ere eragin ditzake.

\section{Ololiuqui}

Cristobal Colonen garaiaren aurreko hitz honek landare igokari baten lorea izendatzen du: Ipomea violacea landarearen lorea eta LSDaren aitzindari den azido lisergikoaren amida (ergina) ekoizten du. Ergina landare horren hazietan metatzen da eta erreta edo edabean har daiteke. Eragina orokorrean lasaigarria da, nahiz eta batzuetan haluzinazio arinak ere eragin ditzakeen.

\section{Kratom}

Asiako hego-ekialdean lantzen den Mitragyna speciosa landarea kratom ezizenez sartu da drogen merkatuan. Landare hau murtxikatua, infusioan edo erreta hartzen da. Haren osagai psikoaktibo garrantzitsuena mitraginina da eta mu-hartzaile opioideen agonista izateaz gain, $5 \mathrm{HT}_{2 \mathrm{~A}}$ eta $\alpha_{2}$ hartzaileekin ere lotzen da. Dosi baxuetan kokainaren antzeko eragina dauka: euforia, urduritasuna eta desio sexuala areagotzen dira. Dosi altuetan, berriz, morfinak bezalako eraginak sortuko ditu: disforia, zorabioak, izerdia edo miosia, esate baterako. Beste drogekin batera hartuz gero, nahasketa hilgarria izan daiteke.

\subsection{Ketaminaren antzeko substantziak}

Arilzikloalkilaminen taldean sailka daitezkeen substantziak dira; ketamina eta fentziklidinaren (PCP) antzeko egitura duten substantzien taldea osatzen dute. 2010. urtean agertu ziren Europan research chemical substantzia gisa. Guztiek izaten dute eragin pizgarria eta disoziatzailea, jatorrizko drogen antzera. Eragin pizgarria monoamina formako neurotransmisoreen sistemetan eraginda sortzen dute. Eragin disoziatzailea, eragin haluzinatzailearen antzekoa izango litzateke eta glutamatoaren NMDA hartzaileetan eraginda sortzen dute. Substantzia berriak direnez, oso informazio gutxi heldu zaigu haien eragin toxiko akutuei buruz: poztasuna, enpatia, lasaitasuna, ikusmen-haluzinazioak, sentimenen pertzepzioaren areagotzea eta norbere gorputzarekiko disoziazioa. Eragin desiragaitz gisa, aldiz, gehien deskribatuak izan diren eraginak dira: disartria, urduritasuna, antsietatea, ikarakrisiak, gehiegizko bortizkeria, nahasmena, amnesia, etab. Eragin toxikoen artean asaldura psikologiko nahiz neurologiko ertainetatik, koma eta heriotza eragiteraino.

Talde honen barruan, gehien detektatua izan den substantzia metoxetamina izan da. Kasu gehienetan ketaminaren aizuntzaile gisa aurkitu da, hau da, kontsumitzaileak ez zekien metoxetamina hartzen ari zela (14).

\subsection{Bestelakoak}

\section{GHB}

Azido gamma-hidroxibutirikoa (GHB) GABA neurotransmisorearen eratorria da. "Estasi likidoa» ezizenez ezagutzen da, nahiz eta anfetaminaren analogoekin zerikusirik ez izan. Oro har, GHBak nerbio-sistema zentralaren depresioa eragiten du. Hala ere, kasu batzuetan eragin pizgarriak edo sedagarriak izan ditzake dosiaren arabera. Substantzia hau kolore gabekoa, usainik gabekoa eta zapore gabekoa da. Hori dela-eta, ura edo beste edariekin nahasten erraza da. Aho bidez hartzean nabaritzen ez denez, intoxikazioa agertzeko arriskua altua da. Menpekotasuna sortzeko ahalmen handia ere badauka. Eraginak hartu eta 5-10 minutura agertzen dira eta 1-3 ordu iraungo dute. Eragin horiek oso aldakorrak dira kontsumitzaile batetik bestera eta, gainera, ezinezkoa da aldez aurretik jakitea zer eragin agertuko diren. Gaindosiaren ondorioz, logura, hipotonia, buruko mina eta nahasmena agertuko dira. Kasu larrietan koma eta heriotza ager daitezke arnas depresioaren ondorioz. Abstinentzia-sindromearen ondorioz, loezina, antsietatea, goragaleak, takikardia, dardarak, karranpak eta izerdia ager daitezke. Normalean 3-10 egun iraungo du abstinentzia-sindromeak, baina kasu batzuetan hilgarria ere izan daiteke. 


\section{Krokodiloa}

«Krokodiloa» da kalean erabiltzen den hitza desomorfina opioide semisintetikoa izendatzeko. Droga hau aho bidez eta bereziki zain bidez hartzen da. Azken urteotan, konposatu honen erabilera Europan zehar zabaldu da, garestia eta topatzeko zaila den heroinaren ordezko gisa. Izena kontsumitzaileengan sortzen dituen azaleko ultzera berdeengatik datorkio, krokodilo baten itxura ematen baitute. Horiek sintesi-prozesuan sortzen diren hondakin eta ezpurutasunen ondorioz agertuko dira. Hondakin horiek azalaren narritadura, ultzera berdeak eta tronboflebitisa eragingo dituzte krokodilo xiringatzen den eremuan. Desomorfina klandestinoki sintetizatzen da kodeinatik abiatuz, merkeak eta lortzeko errazak diren produktuak erabiliz eta laborategiko tresneria arrunta behar duten erreakzio kimiko errazez baliatuz. Desomorfina mu-hartzaile opioideen agonista ahaltsua da. Euforia, sedazioa eta analgesia eragingo ditu. Morfinak baino eragin azkarragoa eta indartsuagoa dauka. Hala ere, toxikotasuna eta konbultsioak eragiteko joera ere handiago da. Oro har, goragaleak, gorakoak, idorreria, gernu-erretentzioa, konbultsioak eta heriotza ekar litzakeen arnasa-depresioa ager daitezke (15).

\section{Ondorioak}

Egun, gure artean substantzia psikoaktibo berriek duten agerpena oso eskasa bada ere, gero eta handiagoa da urtez urte. Substantzia horien zenbatekoa eta merkaturatzea mugaezina denez, talde horrek gizarteari eragin ahal dizkion balizko kalteak zenbatezinak dira. Izan ere, legez kanpo ez dauden substantziak izanik, kontsumitzaileek droga hauek eskuratzeko duten ahalmena oso handia $\mathrm{da}$, batez ere Internet sareak eskaintzen dituen erraztasunak kontuan izanda. Horri, substantzia bakoitzaren inguruan dugun ezjakintasuna gehitzen badiogu, balizko arazoaren nondik norakoaz jabetu ahal izango dugu. Izan ere, gorago azaldutako substantzia gehienen ezaugarri farmakologikoei buruz ezer gutxi dakigu. Legez kanpoko laborategietan ekoizten dira eta ez dakigu zein baldintzatan, baina gainera bertan lortutako produktuen inguruan ere ez dakigu askorik, ezta toxikotasunari buruz ere. Etorkizunean arazo larri bilaka ez daitezen, kontsumitzaileei informazio egokia helaraztea izan daiteke balizko kalteak minimizatzeko aukerarik egokiena.

\section{Erreferentzia bibliografikoak}

1. United Nations Office on Drugs and Crime. World Drug Report 2015. Vienna: United Nations publication, Sales No. E.15.XI.6; 2015.

2. Observatorio Europeo de las Drogas y las Toxicomanías. Informe Europeo sobre Drogas 2016: Tendencias y novedades. Luxemburgo: Oficina de Publicaciones de la Unión Europea; 2016.

3. Delegación del Gobierno para el Plan Nacional sobre Drogas [Internet]. Encuesta sobre alcohol y otras drogas en España, EDADES 2015. Madrid: Ministerio de Sanidad, Servicios Sociales e Igualdad, Secretaría de Estado de Servicios Sociales e Igualdad; 2015 [cited 2017-5-25]. Available from:

http://www.pnsd.msssi.gob.es/profesionales/sistemas/nformacion/sistemalnformacion/encuest as_EDADES.htm

4. Colectivo Energy Control [Internet]. Servicio de análisis de sustancias 2014. Barcelona: Energy Control; 2014 [cited 2017-5-25]. Available from: http://energycontrol.org/files/pdfs/INFORMEESTATAL-2014_DEF.pdf

5. Asociación Ai Laket!! Euskadi Elkartea [Internet]. Composición de drogas ilícitas Euskadi 2014". Vitoria-Gasteiz: Asociación Ai Laket!! Euskadi Elkartea; 2014 [cited 2017-5-25]. Available from: http://www.ailaket.com/?p=4131

6. European Monitoring Centre for Drugs and Drug Addiction. The internet and drug markets, EMCDDA Insights 21. Luxembourg: Publications Office of the European Union; 2016

7. Delegación del Gobierno para el Plan Nacional sobre Drogas [Internet]. Legislación Española sobre Drogas. Ministerio de Sanidad, Servicios Sociales e Igualdad, Secretaría de Estado de Servicios Sociales e Igualdad; 2017 [cited 2017-5-25]. Available from: http://www.pnsd.msssi.gob.es/pnsd/legislacion/ 
8. Dargan P, Wood D. Novel Psychoactive Substances: Classification, Pharmacology and Toxicology. [London]: Academic Press, 2013.

9. Panenka WJ, Procyshyn RM, Lecomte T, MacEwan GW, Flynn SW, Honer WG, et al. Methamphetamine use: a comprehensive review of molecular, preclinical and clinical findings. Drug Alcohol Depend. 2013 May 1;129(3):167-79.

10. Debruyne D, Le Boisselier R. Emerging drugs of abuse: current perspectives on synthetic cannabinoids. Subst Abuse Rehabil. 2015;6:113-29.

11. Baumann MH, Partilla JS, Lehner KR. Psychoactive "bath salts": not so soothing. Eur J Pharmacol. 2013 Jan 5;698(1-3):1-5.

12. Cottencin O, Rolland B, Karila L. New designer drugs (synthetic cannabinoids and synthetic cathinones): review of literature. Curr Pharm Des. 2014;20(25):4106-11.

13. Musselman ME, Hampton JP. "Not for human consumption": a review of emerging designer drugs. Pharmacotherapy. 2014 Jul;34(7):745-57.

14. Katselou M, Papoutsis I, Nikolaou P, Spiliopoulou C, Athanaselis S. A "krokodil" emerges from the murky waters of addiction. Abuse trends of an old drug. Life Sci. 2014 May 2;102(2):81-7.

15. Nogué S, Galicia M, Parra M, To-Figueras J. Urgencias asociadas al consumo de metoxetamina. Primeras descripciones en España de esta nueva droga. Med Clin (Barc). 2015 Nov 6;145(9):4167. 